\title{
人歯牙の含有水銀およびカドミウム量に関する研究
}

\author{
九州歯科大学大学院篓学研究科第 2 口腔外科学専攻 (指導 : 池尻 茂教授) \\ 九州菌 科」大 学 外 科学 教 室 (指導: 草場威棱夫教授) \\ 北村晃 \\ （本淪文要旨の一部は，昭和49年 5 月25日，第34回九州画科学会総会で発表した。）
}

\section{Study on Mercury and Cadmium Concentration in Human Teeth}

By

Akira Kitamura

Second Department of Oral Surgery (Director: Prof. Shigeru Ikejiri)

Department of Surgery (Director: Prof. Izuo Kusaba)

Kyushu Dental College, Kitakyushu, Japan.

The metabolism of heavy metal has been investigated by atomic absorption spectrophotometry but the quantity of mercury and cadmium, which are frequent causes of pollution, in human teeth has not been determined well.

For this research, therefore, measurements were taken of mercury and cadmium levels through precise basic researches. Mercury was measured by non-flame circulation vapor caused by reagent and cadmium by acetylene-air combustion.

The teeth, obtained randomly from three different geographic areas, were defined as dry weight and were ashed by perchloric acid. Then the mercury and cadmium contents were determined.

1. The average mercury level in normal fifty seven teeth was $0.055 \mu \mathrm{g} / \mathrm{g}$. The normal teeth had no significant differeneces among sex, age, type of teeth and geographic regions.

2. Eight normal deciduous teeth had $0.057 \mu \mathrm{g} / \mathrm{g}$ of mercury level and fourty nine permanent teeth had $0.055 \mu \mathrm{g} / \mathrm{g}$. There were no significant differences between the two groups.

3. The carious teeth were divided into $\mathrm{C}_{2}$ (6 cases), $\mathrm{C}_{3}$ (34) and $\mathrm{C}_{4}$ (66) and the averages of mercury concentration were $0.081 \mu \mathrm{g} / \mathrm{g}, 0.069 \mu \mathrm{g} / \mathrm{g}$ and $0.075 \mu \mathrm{g} / \mathrm{g}$ respectively. The four degree of caries group contained significantly heigher level than the normal teeth. The mercury levels in carious teeth require further examination.

4. The amalgam filling and endodontically treated teeth which were excluded from statistical dealing indicated more than $0.4 \mu \mathrm{g} / \mathrm{g}$ of mercury level.

5. The cadmium concentration in twenty five of normal teeth was $0.52 \mu \mathrm{g} / \mathrm{g}$ on the average.

6. The mercury and cadmium levels in enamel tissue were apparently higher than those of dentine. 
The fundamental study made it possible to determine the concentration of mercury and cadmium burden in teeth and to obtain statistical data attributable to region, sex, year, carious degree and tissue from the standpoint of enviromental health. The findings on mercury in this study, in particular, presented base levels expected to be found in general population.
A. 緒言
次
a . 含有 $\mathrm{Cd}$ 量
B . 基礎的検討
I 測定装置・測定方法および測定值の算定
b . 含有Cd量の年令別・性別・地域別差
a. 試薬

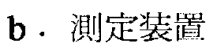
c . 還元法
d · 測定值の算定
II 水銀量測定に関する基礎実験
c . 䣼菌の含有Cd量
d . 爾種別含有Cd量
$\mathrm{e}$. 橉牙組織別含有 $\mathrm{Cd}$ 量
IV 小括
E. 考察ならびに総括
F. 絬語
引用文献
a . ランプ安定時間
b . 標準液による吸光度
c. 過塥素酸の吸光度
d. 過塩素酸の干渉とその補正
e ．その他の干渉と回収実験

III カドミウム量測定に関する基礎実験
a . ランプ安定時間の検討
b ．ガスバーナーの高さ
c、標準液に上る吸光度
d. 過塩素酸の干涉
e . 光散乱の補正

IV 小括

C. 歯牙含有水銀量に関する検討

I 一般的事項
a. 対象検体
b . 試料の作製方法

II 健常齒牙の含有水銀量

III 無作為蒐集菌牙の含有水銀量
a . 含有水銀量
b . 含有水銀量の性別・地域別差
c . 含有水銀量の年令別・性別差
d . 鹋雨の含有水銀量
e . 菌種別含有水銀量
f . 菌牙組織別含有水銀量
IV 小括

D. 奥牙含有カドミウム $\langle$ Cd $)$ 量に関する検討
I 一般的事項
II 健常歯牙の合有 $\mathrm{Cd}$ 量
III 無作為蒐集霖牙の含有 $\mathrm{Cd}$ 量

\section{A. 緒言}

原子吸光分析法の碓立にともない，生体内微量金属に 関する研究は，枚举们々まがない。しかし，歯牙含有 の微量金属については, 十分な検討が行なわれていると はいい難いようである。

ことに，最近，環境污染金属として注目されている水 銀の歯牙含有量については，いまだ報告をみない，この ことは, 䨑牙含有の水銀定量法が，今日，なお，確立さ れていないととによるものと考えられる。

この度，原子吸光分析法に上り，菌牙の含有水銀量を 測定し得たので，定量法を概説し，歯牙含有水銀量に関 する若干の検討結果を報告する。

なお，同じく污染金属として知られているカドミウム の夹牙含有量についても，2，3の検討を行なったの で，その概要もあわせて報告する.

\section{B. 基礎的検討}

I 測定装置・測定方法および測定值の算定

$$
\text { a. 試萫 }
$$

水銀量の測定に使用した主な武萝は，原子吸光用水銀 標準液， $10 \%$ 塩化第 1 錫， $50 \%$ 硫睃溶液， $2 \%$ 硫酸酸性 過マンガン酸カリウムであり，カドミウム量の測定に は，原子吸光用カドミウム標準液を用いた（表 1)。

また，試料とした釆牙の湿式灰化には，過塩素酸を使 用し脱灰溶解した。

以上の主な試薬は，いずれも和光純茧製で，精密分析 用のもの在用い，水は全て二回蒸留水を使用した。な お, 使用ガラス器具などは, 全て化学的に清浄なものを 使用した。
b ～测定装置 
Table 1

Reagents

$\mathrm{Hg}$

Mercury Standard Solution

10\% Stannous Chloride

$50 \%$ Sulfuric Acid

$2 \%$ Potassium Permanganate Sulfate

$\mathrm{Cd}$

Cadmium Standard Solution

Wet ashing

Perchloric Acid

Table 2

Experimental Apparatus

Atomic Absorption Spectrophotometer

Hollow Cathode Lamp

Recorder

Experimental Method

$\mathrm{Hg}$

Non-flame

Circulate vaporize

$\mathrm{Cd}$

Flame

Acetylene-Air combustion

日立207型原子吸光装置および QPD-54 型記録計を用 いた，光源は，日立製の水銀またはカドミウム用中空陰 極ランプを使用した。なお，カドミウム量測定時には， $\mathrm{D}_{2}$ ランプを用いて，その值を補正した（表 2 ）。

ちなみに, 日立 207 型原子四光装置の使用条件の詳細 は，表 3 に表示されている。

c . 還元法

水銀分析には，日立製水銀分析用附属装置を利用し， 長谷川万 $(1972)^{1.22}$, 菅野 $(1973)^{3)}$ の報告に從い, 還 元気化方式を採用した（図 1)。まず，反応容器に一定 量の試料を入れ，水を加えて 100 m とする. ポンプを作 動させ,コック A， B を循環状態にセットして後, 試薬 ビューレットから50\%硫酸溶液 $5 \mathrm{m \ell}, 10 \%$ 塩化第 1 錫溶

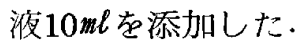

カドミウム分析には，アセチレン・空気混合ガスによ
$\mathrm{HgCl}_{2}$ in wate $\mathrm{r}$

$1 \mathrm{~m} \ell=1,000 \mu \mathrm{g}\left(20^{\circ} \mathrm{C}\right)$

$\mathrm{SnCl}_{2}$

Sulfuric Acid $(1: 20) \quad 60 \mathrm{~m} \ell$

Water $40 m \ell$

Potassium Permanganate $\quad 5 \mathrm{~g}$

Sulfuric Acid $(1: 20) \quad 250 m \ell$

$\mathrm{CdCl}_{2}$ in water

$1 \mathrm{~m} \ell=1,000 \mu \mathrm{g}\left(20^{\circ} \mathrm{C}\right)$

$1-8 m \ell$

Hitachi 207

$\mathrm{Hg}, \mathrm{Cd}, \mathrm{D}_{2}$

QPD 54

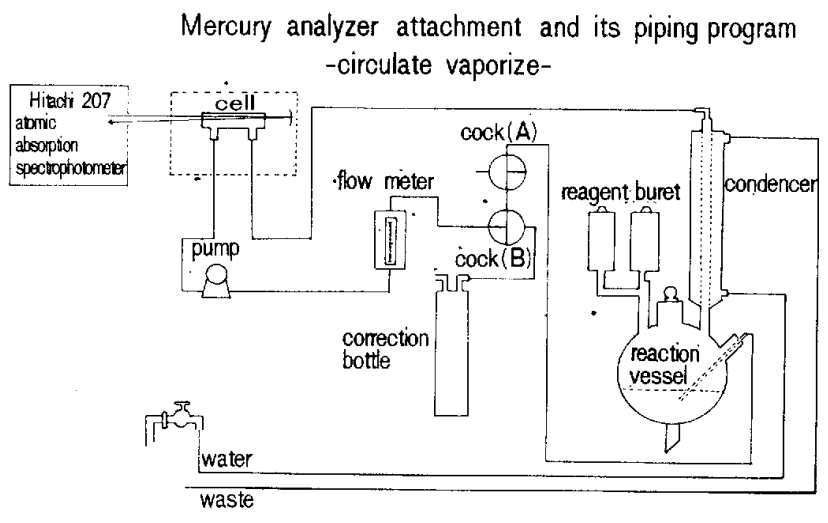

Fig. 1

る燃焼還元法を用いた。

$\mathrm{d}$. 測定值の算定

記録された眀光度を読みとり，標準液による検量線か 
ら，その测定值を算定した．测定值の対比検討に当って は, F-testで分散を吟味し， $\mathrm{t}$ 検定を行ない，有意水準 $5 \%$ 美の有意義性を検討した。

なお，各集団の平均值は，算術平均值（土標準䛊差） で表わした。

II 水銀量測定に関する基礎実験

\section{a . ランプ安定時間}

水銀用中空陰極ランプの出力と光量が安定するまでに は, $6 \mathrm{~mA}$ で, 点灯後約 1 時間を要した (図 2 ). 従っ

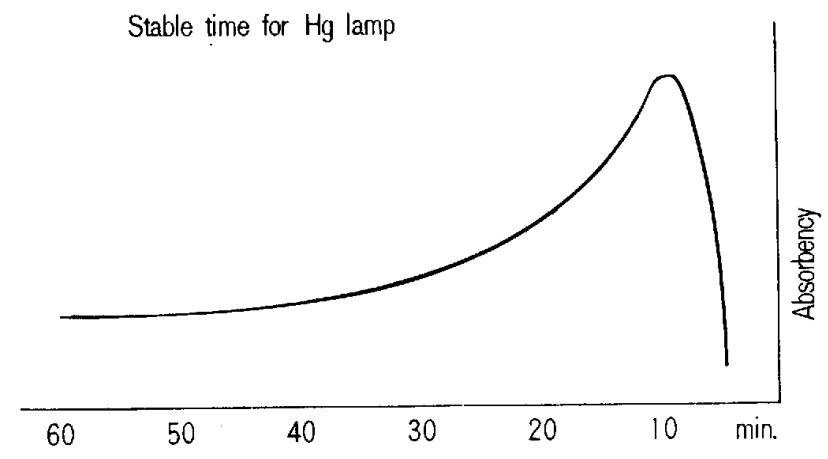

Fig. 2

て, ランプ点灯後約 1 時間半を経過して後, 测定を閆始 することとした。

\section{b. 標準液に上る吸光度の検討}

原子吸光用水銀標準液を 1,000 倍ないし 10,000 倍に稀 釈して，各段階における吸光度を測定した。標準淮を使 用した水銀含有量 $0.1 \mu \mathrm{g}, 0.2 \mu \mathrm{g}, 0.4 \mu \mathrm{g}, 0.6 \mu \mathrm{g}, 0.8$ $\mu \mathrm{g}$ の平均吸光度は, それぞれ $14.3 \mathrm{~mm}, 28.5 \mathrm{~mm}, 57.8 \mathrm{~mm}$ $86.4 \mathrm{~mm}, 115.7 \mathrm{~mm}$ で, 水銀濃度と吸光度は, 直線的な正 の相関を示すととが確認され（図 3 )，その再現性も良

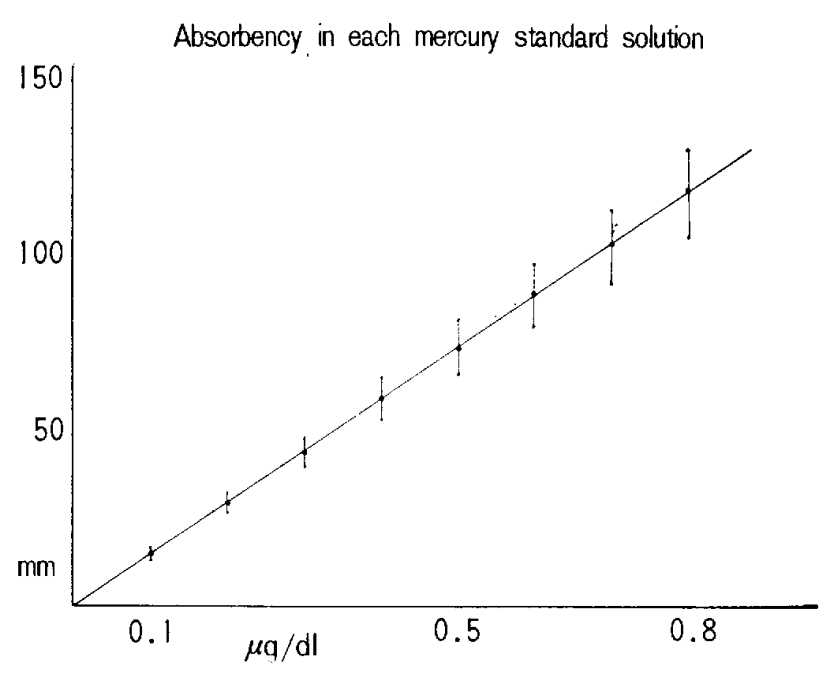

Fig. 3
Table 3 Experimental Condition

\begin{tabular}{l|r|r|c}
\hline & $\mathrm{Hg}$ & $\mathrm{Cd}$ & \multicolumn{1}{c|}{$\mathrm{D}_{2}$} \\
\hline Lamp Current $(\mathrm{mA})$ & 6 & 10 & 20 \\
" Volt (V) & 100 & 100 & 100 \\
Slit width & 1 & 1 & 2 \\
Absorption Sense & 2.5 & 1.8 & 1.8 \\
Coarse & 6 & 5 & 5 \\
\hline
\end{tabular}

Table 4

Absorbency in each mercury standard solution

\begin{tabular}{r|r|r|r|r|r|r}
\hline $\begin{array}{r}\text { Times } \\
\mu \mathrm{g} / \mathrm{d} 1\end{array}$ & 1 & \multicolumn{1}{|c|}{2} & \multicolumn{1}{c|}{3} & 4 & 5 & \multicolumn{1}{|c|}{$\begin{array}{l}\text { Mean } \\
\text { S.D. }\end{array}(m m)$} \\
\hline 0.1 & 16.0 & 15.0 & 13.5 & 16.0 & 14.3 & $14.3 \pm 1.7$ \\
0.2 & 31.8 & 33.0 & 27.3 & 32.0 & 28.5 & $28.5 \pm 3.4$ \\
0.3 & 47.5 & 45.8 & 41.3 & 47.5 & 42.5 & $42.9 \pm 1.7$ \\
0.4 & 63.5 & 61.5 & 55.3 & 65.0 & 57.0 & $57.8 \pm 6.9$ \\
0.5 & 79.5 & 77.0 & 69.0 & 80.1 & 71.0 & $72.1 \pm 8.3$ \\
0.6 & 95.5 & 92.5 & 83.0 & 95.3 & 85.5 & $86.4 \pm 9.5$ \\
0.7 & 111.0 & 107.5 & 96.8 & 110.8 & 100.0 & $100.6 \pm 11.5$ \\
0.8 & 127.3 & 123.0 & 110.8 & 130.5 & 113.5 & $115.7 \pm 13.8$ \\
\hline
\end{tabular}

好であった（表 4)。

\section{c. 過塩素酸の吸光度}

歯牙の湿式灰化に使用する過塩素酸の吸光度について 検討した. 先に, 水銀標準液の吸光度を測定した場合之 同椂な条件で，特級過塩素酸 $1 m \ell(1 \%), 2 m \ell(2 \%)$ の吸光度を測定したところ, それぞれ8.9（土2.0） mm, 16.8（土3.9）mmにもおよんだ. 值線性の正の相関はみ られるが, 過塩素酸の干渉には，なお十分の検討が肝要 なととが判明した（図4)。

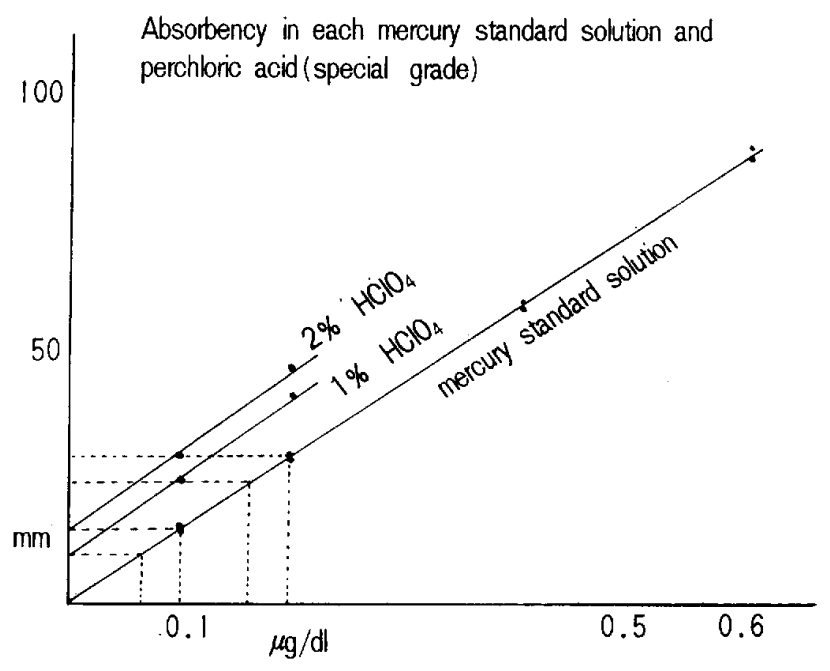

Fig. 4 
d．過塩素酸の干涉とその補正

$0.1 \mu \mathrm{g}$ あるいは $0.2 \mu \mathrm{g}$ の水銀を含有した， $1 \%$ よび $2 \%$ 特級過塩素酸溶液を作製し，その吸光度を測定し た所, 過塩素酸の量に比例して, 一定の吸光度の上昇が みられた (図 4)，その吸光度の上昇は, 過塩素酸 $1 m \ell$ および $2 m \ell て ゙ ，$ 水銀量に換算して，それぞれ $0.06 \mu \mathrm{g}$, $0.095 \mu \mathrm{g}$ にも相当し，水銀量の測定に際し，無視出来奴 正の干渉がみられた。

その後, 精密分析用の過塩素酸を用い, 同様の検討を 行なったとてろ，0.1 $\mathrm{g}$ の水銀を合有した $1 \%$ 過塩素酸 溶液では, 水銀量の $0.115 \mu \mathrm{g}$ の吸光度を示し, 精密分析 用過塩素酸 $1 \mathrm{ml}$ の吸光度は，水銀量に換算して，0.015 $\mu \mathrm{g}$ 正の干涉をもつにすぎないことが判った（図 5 ）。

このように，水銀量の測定に際し，同じ過塩素酸で も，特級製品と精密分析用褩品で，吸光度に対する干涉 の差がみられることは，酸自体による干渉の差ではな く, 主として試真中に含まれる污染水銀量の差に由来し たものと考元られる. 従って, 以後の崡牙湿式戻化に は，全て，精密分析用過塩素酸を用いた。

又, 過塩素酸で湿式灰化した歯牙試料 $1 m \ell$ t，水銀還

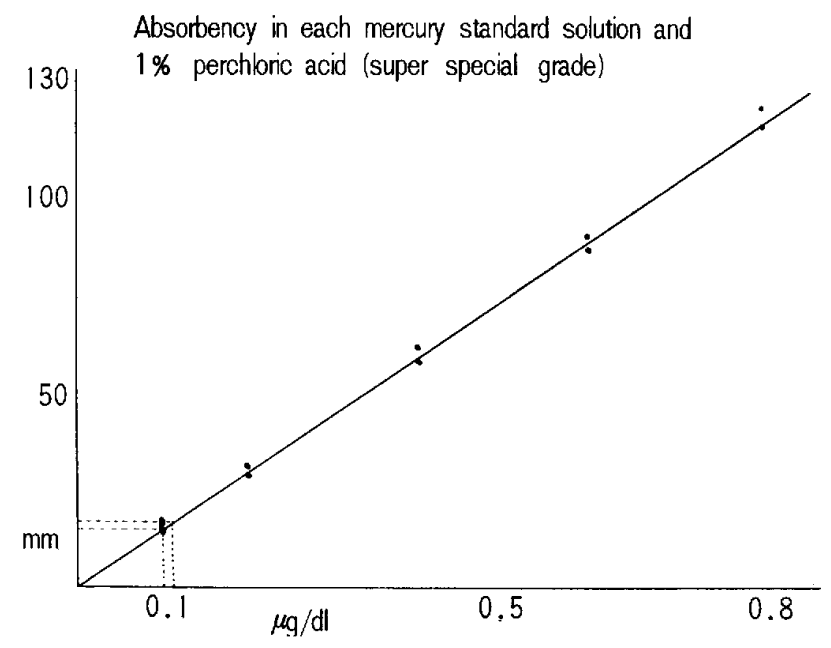

Fig. 5
元気化装置の反心容器に入れ, 水を加えて, $100 m \ell$ とし て水銀量を測定するので，水銀標準液にも， $1 \%$ 割合 で，精密分析用過塩素酸を加えて検量線を作製し，標淮 添加法により，その干渉を除外した。

e. その他の干渉

任意の雪牙 3 本を, それぞれ過塩素酸 $3 m \ell$ ない $8 m \ell$ を用いて浴解し，その $1 \mathrm{~m} \ell$ に水銀 $0.1 \mu \mathrm{g}$ 添加し，さら に水を加えて $100 m \ell$ とした. 本試料の吸光度は, 全ての 試料蔥牙について, 水銀 $0.1 \mu \mathrm{g}$ の標準検量線と同じ吸光 度を示し，回収能も良好であった（図6）。また，この 結果よりして，雨牙中の他種元素に由る干涉は否定さ れ，過塩素酸の干渉をも，十分に除外し得たことが知ら れる。

しかし, 反面，雬牙合有の水銀量は， $0.1 \mu \mathrm{g}$ を基準単 位としては, 測定不能であることも判明した。

依って，感度を10倍にし，0.01\%g在基準単位とする水 銀標準蚹（1％の制合に過塩素酸を添加）を作製し，各 水銀濃度の吸光度を測定した，その結果， $0.01 〜 0.1 \mu \mathrm{g}$ の間でも，十分の直線性が得られるととを確㸾し（図7

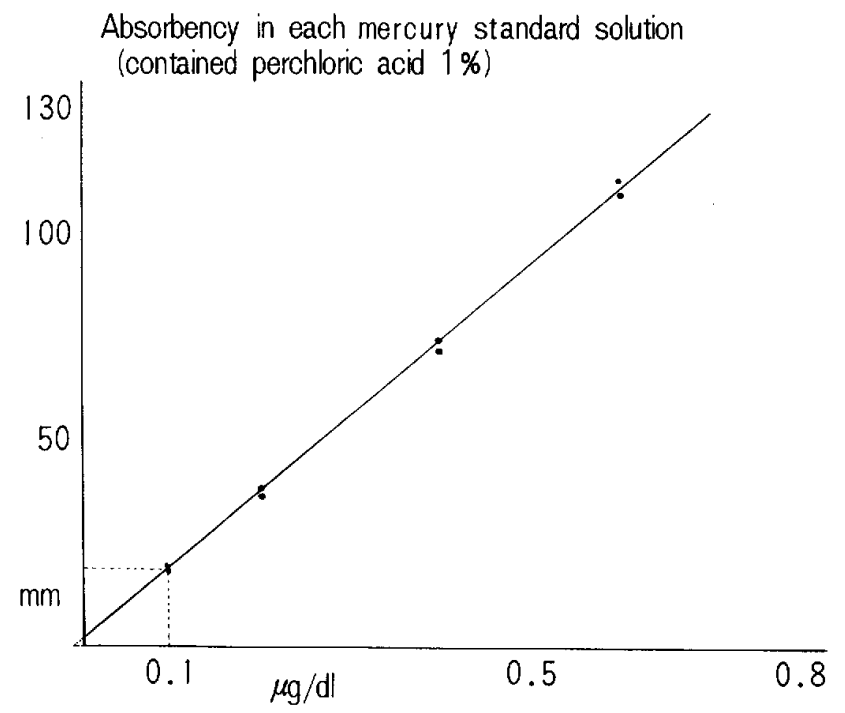

Fig. 6

Table 5

Absorbency in each cadmium standard solution

\begin{tabular}{|c|c|c|c|c|c|c|c|c|c|c|c|}
\hline$\mu \mathrm{g} / m \ell$ Times & 1 & 2 & 3 & 4 & 5 & 6 & 7 & 8 & 9 & 10 & Mean $\pm S . D$. \\
\hline 0.1 & 12.0 & 11.0 & 13.0 & 12.5 & 13.5 & 11.0 & 12.2 & 13.0 & 14.0 & 13.0 & $12.5 \pm 1.0$ \\
\hline 0.2 & 22.5 & 21.5 & 26.0 & 24.0 & 26.0 & 23.5 & 25.2 & 26.0 & 27.0 & 25.5 & $24.7 \pm 1.8$ \\
\hline 0.3 & 35.0 & 32.7 & 40.0 & 37.0 & 39.5 & 36.5 & 39.5 & 40.0 & 41.0 & 39.0 & $38.0 \pm 2.7$ \\
\hline 0.4 & 56.0 & 43.0 & 52.0 & 48.0 & 52.1 & 49.0 & 52.5 & 52.9 & 54.5 & 52.5 & $50.3 \pm 3.6$ \\
\hline 0.5 & 57.5 & 53.5 & 64.5 & 59.5 & 65.0 & 61.0 & 65.0 & 64.5 & 67.0 & 65.0 & $62.3 \pm 4.5$ \\
\hline 0.6 & 68.0 & 65.0 & 78.0 & 71.0 & 78.0 & 72.0 & 78.0 & 77.0 & - & 78.1 & $73.9 \pm 5.0$ \\
\hline
\end{tabular}


，以後の本実験を行なった。

III カドミウム量測定に関する基礎失験

a 、ランプ安定時間

カドミウム用中空陰極ランプの出力と光量は， $10 \mathrm{~mA}$ で, 点灯約 20 分後に安定した. 従って測定は点灯 30 分後 に開始した（図8）。以下，カドミウム在 Cd と略記す る.

b ．ガスバーナーの高さ

バーナーの長軸とランプの光軸とを一致させた後, バ

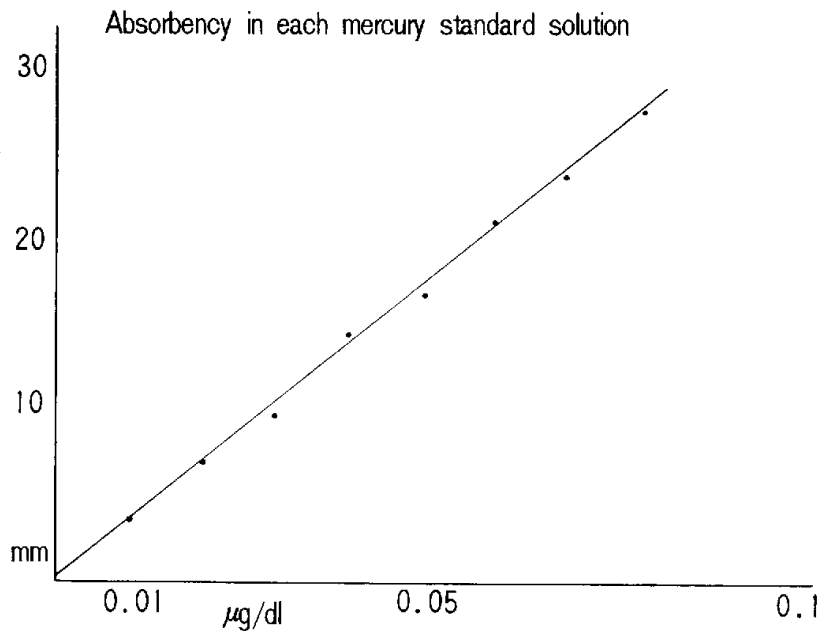

Fig. 7

Stable time for Cd lamp

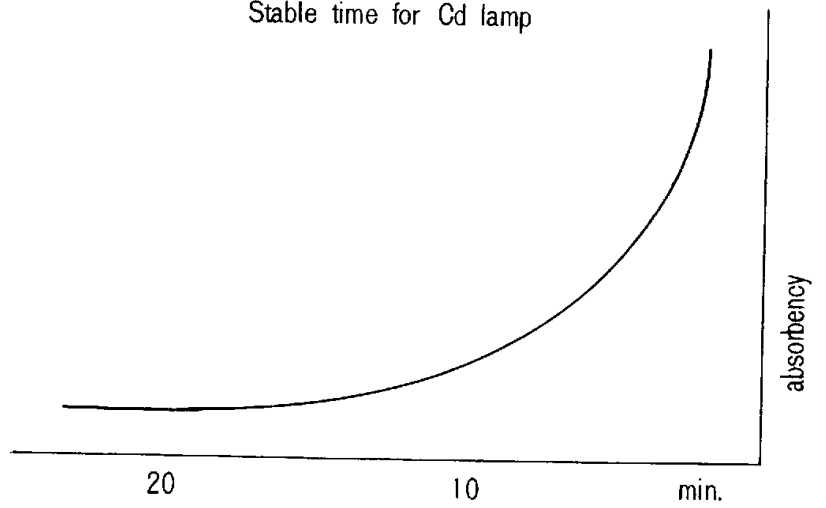

Fig. 8

Table 6

Weight change for four weeks

\begin{tabular}{c|c|c}
\hline Weeks & Cases & Weight Change $(\%)$ \\
\hline 1 & 20 & 100 \\
2 & 20 & $95.8 \pm 2.4$ \\
3 & 20 & $93.5 \pm 1.6$ \\
4 & 20 & $93.5 \pm 1.6$ \\
\hline
\end{tabular}

ーナーの高さを調節した。 バーナ一部の目盛を 0.5 より

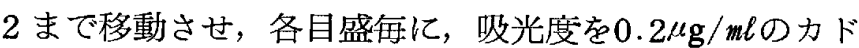
ミウム標準液を用いて調查した。いずれの目盛の位置で も測定可能であった（図 9 ）が，目盛 1 の高さの場合が 最も吸光度がよく，ノイズも少なく，しかも安定してい た。

c、標準液による吸光度

原子吸光用 Cd 標準液を稀䣋して， $0.1 \mu \mathrm{g} / \mathrm{m} \ell$ から 0.6 $\mu \mathrm{g} / m \ell$ までの各種濃度のCd水溶液を調製し，その吸光度 を測定した．連日10日間に亘って行なった再現性も良好 で（表 5 ），濃度と吸光度怔の相関を示して，十分の 直線性が認められた（図10）。

d. 過塩素酸の干渉

下記した 5 試料について吸光度を测定し， $\mathrm{Cd}$ 標準液

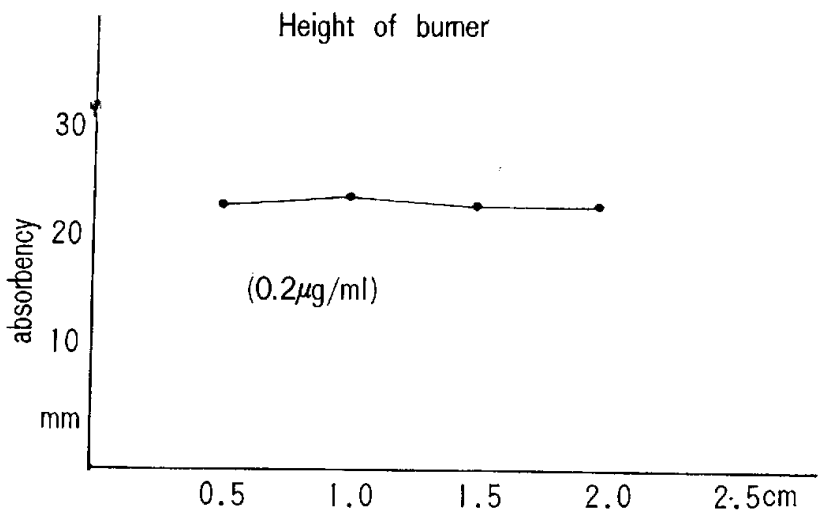

Fig. 9

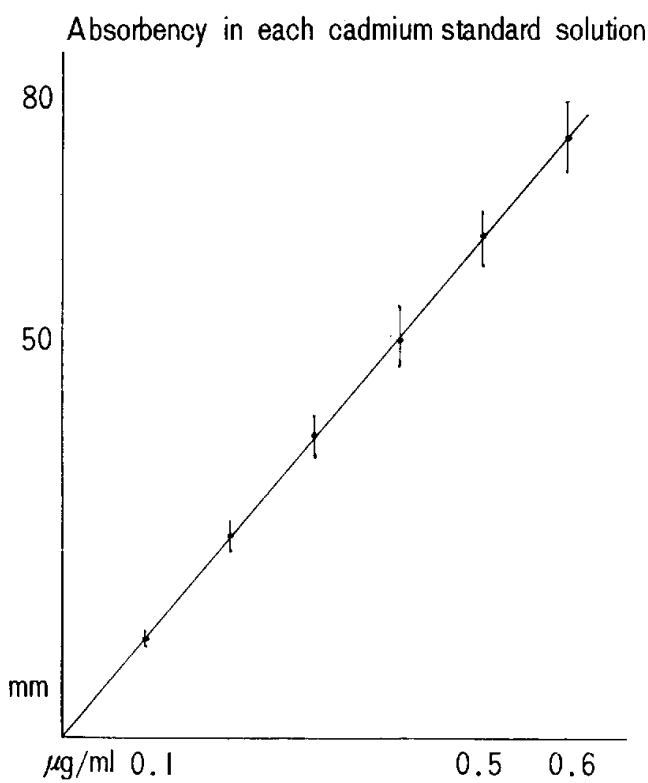

Fig. 10 
による吸光度と対比検討した（図11）。

試料 1 ; 過塩素酸 10 倍稀釈液.

試料 2 ; 過塩素酸 $1 \mathrm{~m} \ell \mathrm{lCCd} 0.5 \mu \mathrm{g}$ を添加し, 水を加光 て $10 m \ell$ とした溶液.

試料 3 ; 過塩素酸 $1 m \ell に C d 1.5 \mu \mathrm{g}$ を添加し, 水を加え て10mととした溶液.

試料 4 ; 過塩素酸 $1 m \ell て ゙$ 菡牙を湿式灰化した溶液の 10 倍稀釈没。

試料 5 ；試料 4 にCd0.5 $\mathrm{g}$ を添加した溶液.

以上の各試料のうち，試料 2 と 3 ，打よび試料 4 と 5 の败光度の差は, $\mathrm{Cd}$ 標準液による $0.1 / \mathrm{g} / m \ell, 0,05 \mu \mathrm{g} /$ $m \ell$ 吸光度とよく一致し，過堭素酸は， $\mathrm{Cd}$ の吸光度に 直接の干涉作用は示さない，しかし過塩素酸の10倍稀䧽 液は水（基線）に比へ，記録紙上で，約 $2 m m$ 上䒜し吸光 度として表現されている，乙の過塩素酸による影響を除 外するために，Cd 標準液には，過塩素酸を添加し，そ の10倍稀釈液を用いて，検量線を作製することとした。

e. 光散乱の補正

歯牙合有のCd 量測定に際しては, 光散乱による内部 干渉の補正も，重要な一課題である。この補正のために

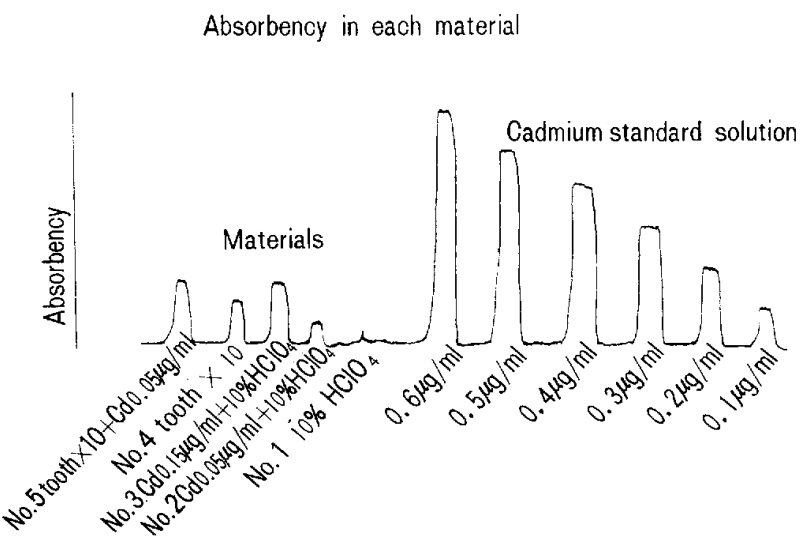

Fig. 11

Absorbency in each material and cadmium standard solution

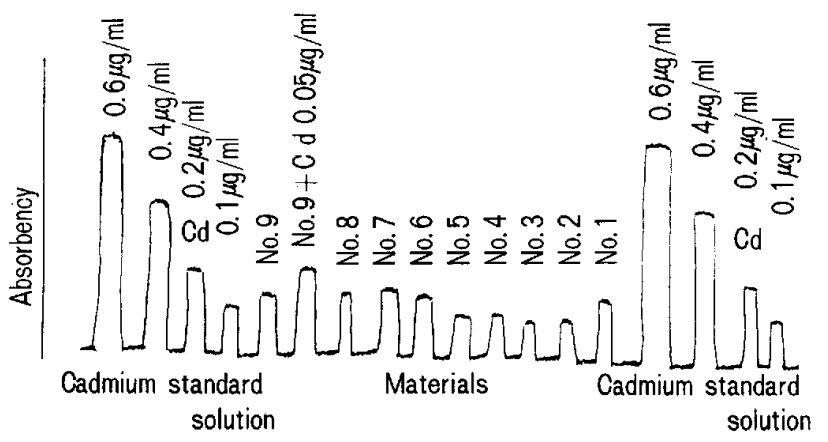

Fig. 12
は，日立製 $\mathrm{D}_{2}$ ランプを使用し，以下の検討を行なった。

まず，Cd 標準液と，歯牙を過笽素酸で湿性灰化した

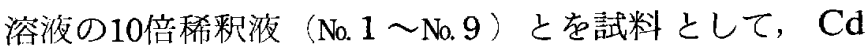
用中空陰極ランプで财光度を測定した（図12）。号続き 同一試料の吸光度を $\mathrm{D}_{2}$ ランプでも測定した（図13）。 この両者の吸光度を対比検討すると， $\mathrm{D}_{2}$ ランプで, $\mathrm{Cd}$ 標準液は, 過塩素酸添加に由ると考えられる $2 m m$ 前後の 吸光度を示すにすぎないが，№. 1 〜No. 8 の蒾牙試料で は, 可成りな吸光度がみられた。

しかし，Cdを0.05 $\mathrm{g} / \mathrm{ml}$ の割合に添加した函牙試料・ №. 9 の吸光度の差は, $\mathrm{Cd}$ 標準液による $0.05 \mu \mathrm{g} / \mathrm{ml}$ の吸光 度と，よく一致して回収能もよく(図12），また， $\mathrm{D}_{2}$ ランプによる吸光度は，同じ值を示している（図13）。

従って，他種元素の光散乱に上る内部干渉を， $\mathrm{D}_{2}$ ラ ンプを用いて補正するととが出来る。すなわち，曾牙含 有のCd量は， $\mathrm{Cd}$ 用中空陰極ランプで測定した财沦度よ り， $\mathrm{D}_{2}$ ランプで測定した吸光度を差引いた值で，算定 されねばならない。

ちなみに，Cd 標集液について，乙の值を求め，検䥣

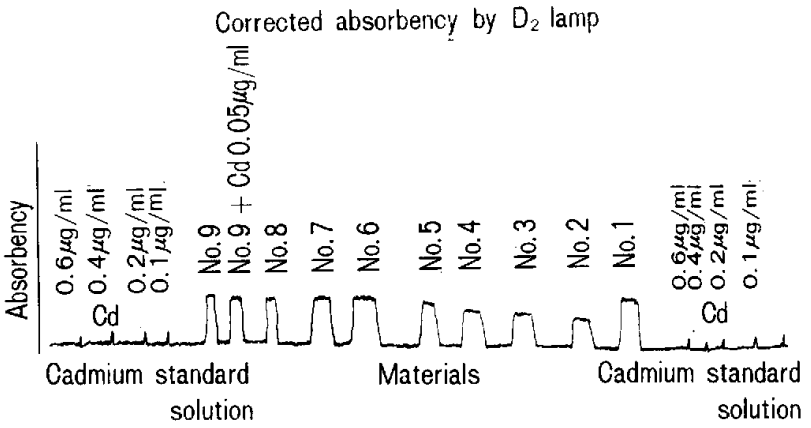

Fig. 13

Correlation between absorbency by $\mathrm{Cd}$ lamp and $\mathrm{D}_{2}$ lamp

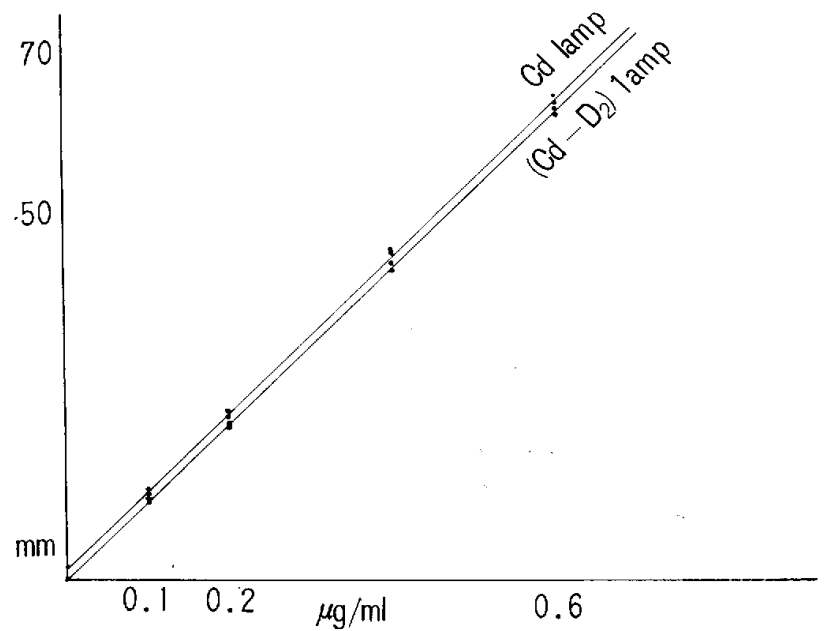

Fig. 14 
線を引くと，十分な直線性をもち，しかも原点を通過す る検量線を描きうる(図14)。乙の方法でも，過塩素酸 の影響を除外し得る.

\section{IV 小括}

日立 207 型 原子吸光装置を用いて，图牙含有の水銀お よび Cd 量を測定するために，若干の基礎的検討を行な った。

1. 水銀分析には，日立製水銀分析用附臀装置を利用 して，還元気化方式を採用し， $\mathrm{Cd}$ 分析には，アセチレ ン・空気混合ガスによる燃焼還元法を用いた。その結 果, 標準液の濃度と吸光度は正比例し, 直線的な検量線 をひきうることを知った：また吸光度の再現性もよい。

2. 試料菌牙の湿式圧化には，精密分析用過塩㨞酸を 使用する．水銀あるいは Cd の吸光度に対する過塩素酸 の干渉ないし影響は，標準添加法を用いて除外しうる.

3. $\mathrm{Cd}$ の吸光度に対する队部干涉は， $\mathrm{D}_{2}$ ランプを用 いて除去・補正しうる。

以上の結果から，日立 207型原子吸光装置を用いて， 畨牙中の水銀および Cd 量を，十分な精度で，分析定量 しうることが確認された。

な抢，本法による水銀量測定は，総水銀量を主な対象 としたものである.しかし，雪牙を試料とした今回の測 定值は，主として無機水銀量を示しているものと考えら れる。

\section{C. 雪牙含有水銀量に関する検討}

\section{I 一般的事項}

a. 対象検体

北海道大夕張地区（A） - 北九州市地区（B） - 宮崎 県諸塚地区（C）で，雷科外来治療に際し，抜去された 菌牙を刘象検体とした。検体とした健常函牙，瀜曾な

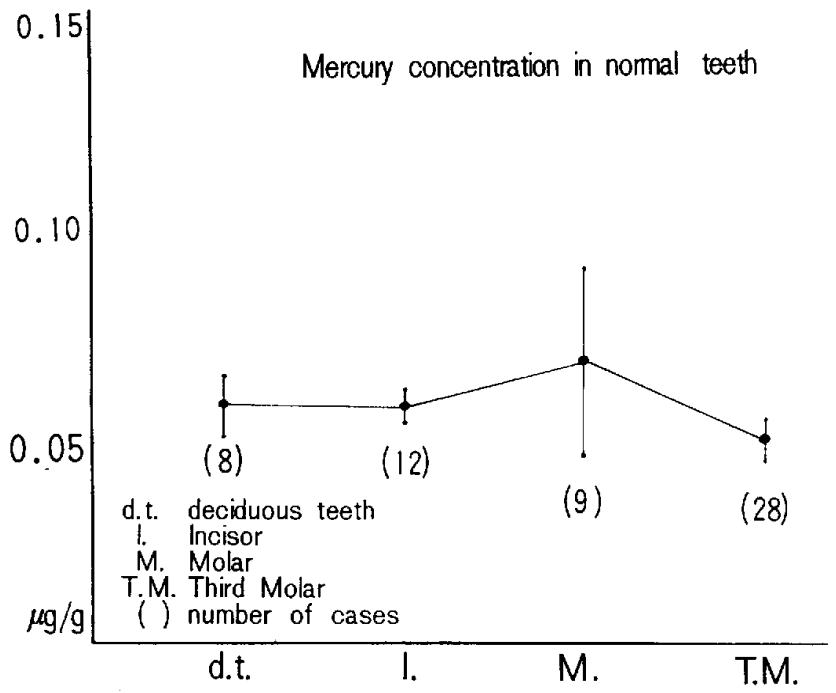

Fig. 15
ど，すべて無作為に蒐集されたものである，検体総数は 176曾牙で，うち 健常菌牙は59検体であった。

b. 試料の作製法

検体として蒐集された蒾牙の歯石，歯周組織および裂 溝附着物などは可及的に除去した。

その後，検体歯牙をそれぞれ，硬質ガラス製スピッツ ダラスに保存し，真空デシケーター（シリカゲル）を用 いて乾燥した。重量は, 約 4 週間後に93.5\%に減少し, その後の変動はほとんどみられなかった（表6）．従っ て，真空デシケーター中で，4週間乾燥した岿牙重量 を，基礎的な乾燥重量とし，単位重量当りの水銀量を算 定した。なお，一部蒛牙は乳棒で軽打し象牙質きエナメ ル質に分離した。

このようにして乾燥した検体䨑牙の $0.1 \sim 0.3 \mathrm{~g}$ に，過 塩素酸 $1 m \ell$ を加えて，試験管中に密封静置すると， 3 〜 5 日で完全に溶解（湿式灰化）し，透明な溶液となる. その後に水を添加して $100 m \ell$ とし水銀の分析定量試料と した.

\section{II 健常藩牙の含有水銀量}

健常崡牙・59検体のうち，含有水銀量が検出定量され た菡牙は，57検体にもおよんだ、すなわち，乳粜・8検 体, 永久画・49検体である. 永久雪を歯種別にみると, 前曾は12検体，目䨑は 9 検体，智菌は28検体である。

これら各群の平均含有水銀量は，乳菌が0.0568（士 $0.0081) \mu \mathrm{g} / \mathrm{g}$ であり, 永久粷のうち, 前米は0.0567（士 $0.0032) \mu \mathrm{g} / \mathrm{g}$, 田歯は, $0.0690( \pm 0.0222) \mu \mathrm{g} / \mathrm{g}$, 智 函は0.0486（士0.0062） $\mu \mathrm{g} / \mathrm{g}$ である. 各群間の差に有 意はみられない，また，永久函49検体の平均含有水銀量 は, $0.0552 （ \pm 0.0102 ） \mu \mathrm{g} / \mathrm{g}$ で, 乳雨との差に有意は ない（図15）。

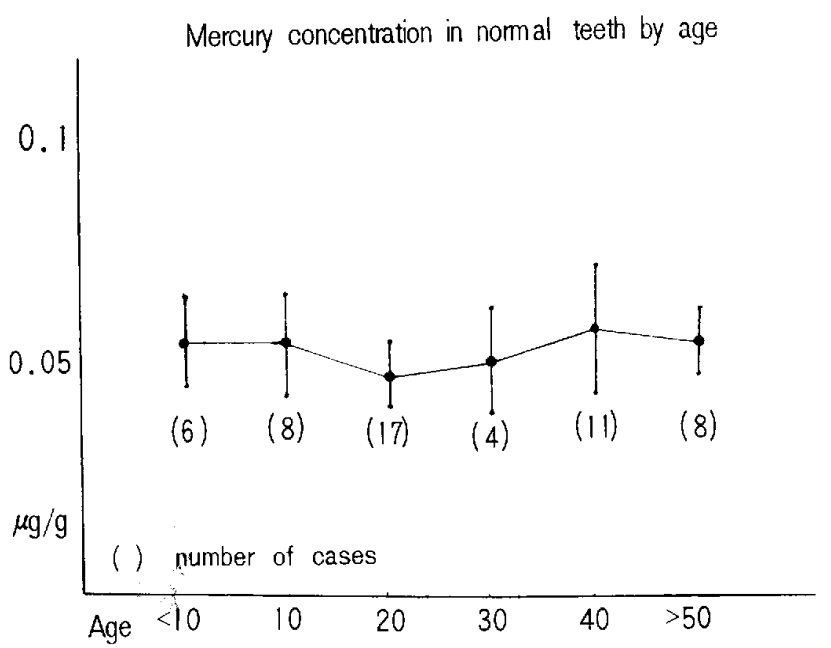

Fig. 16 
さらに，各年代別に，その平均含有水銀量を対比して みても，各年代とも $0.05 \mu \mathrm{g} / \mathrm{g}$ 前後值を示し，相互間の 差には有意はない（図16）。

また，永久雬 49 検体のうち，男性・ 25 検体の平均含有 水銀量は0.0598（ $\pm 0.0232 ） \mu \mathrm{g} / \mathrm{g}$ であり，女性・24検 体では，0.0504（ $\pm 0.0055 ） \mu \mathrm{g} / \mathrm{g}$ である. ての両者間 の差にも，有意はない。

次に，健常歯牙59検体を地区別に分類すると，検体数 はA地区・15検体, B 地区・34検体, C地区・10検体々 なり，それぞれの平均含有水銀量は，0.0630（ $\pm 0.0137 ）$ $\mu \mathrm{g} / \mathrm{g}, 0.0520( \pm 0.0051) \mu \mathrm{g} / \mathrm{g}, 0.0553( \pm 0.0131)$ $\mu \mathrm{g} / \mathrm{g}$ である. 各群相互間の差に有意はない.

なお，健常菌牙で，60才台の 1 例に，0.208 $\mathrm{\mu g} / \mathrm{g}$ 之高 い值がみられているが，本例は，A地区の症例である.

\section{III 無作為蒐集歯牙の含有水銀量}

\section{a . 含有水銀量}

男性・75検体，女性・101検体計176菌牙の含有水銀量 を測定した，水銀量の $0.1 / \mathrm{g} / \mathrm{g}$ 以下の検体が， 176 検体 中121検体 $(68.8 \%)$ 占めて最も多く, 次いで $0.1 \mu \mathrm{g} / \mathrm{g}$ 以上 $0.2 \mu \mathrm{g} / \mathrm{g}$ までの検体が 176 検体中 35 検体 $(19.9 \%)$ であった.この両群で，計 $88.7 \%$ 占めている。

$0.4 \mu \mathrm{g} / \mathrm{g}$ 以上の検体も 9 検体にみられるが，乙れらの 霜牙は, いずれも根管治療中の雪牙・根充荬牙もしくは アマルガム充填蒾牙などであった，一方，含有水銀量を 検出出来なかった検体は，4歯牙にすぎない，従って， これら13検体を除いた男性・71検体, 女性・92検体, 計 163歯牙を主な対象として，以下の検討を行なった。

男性・71菌牙の平均含有水銀量は， $0.0712( \pm 0.0074)$ $\mu \mathrm{g} / \mathrm{g}$ で，女性・92䨑牙のそれは，0.0645（ $\pm 0.0019 ）$ $\mu \mathrm{g} / \mathrm{g}$ であり，全検体の平均含有水銀量は， 0.0674 (土 0.0048) $\mu \mathrm{g} / \mathrm{g}$ であった（表 7 ）。

b . 含有水銀量の性別・地域別差

北海道大夕張地区（A）・北九州市地区（B）・宮崎 県諸塚地区 (C) の三地区別に全検体を分類し, 各地区 毎に男女間の歯牙含有水銀量を比較検討したところ, 三 地区とも性差はみられなかった。

また，男性の三地区相互間における歯牙含有水銀量の 差にも，有意はみられなかった，女性では，C地区の $0.0896( \pm 0.0119) \mu \mathrm{g} / \mathrm{g}$ は， B 地区の0.0507 ( \pm 0.001 4) $\mu \mathrm{g} / \mathrm{g}$ に比へ，明らかに高值であった. しかし，乙 のいずれの值も，女性・ -92検体の平均含有水銀量 0.0645 ( \pm 0.0019$) \mu \mathrm{g} / \mathrm{g}$ との差には, 有意がみられなかった（表 7).

c . 含有水銀量の年令別・性別差

年令を10才毎に区分し，また各年代を男女別に分ち， 歯牙含有の水銀量を対比検討した。10才末満では, 平均 含有水銀量は $0.0926( \pm 0.0123) \mu \mathrm{g} / \mathrm{g}$ で，10才台では $0.0871( \pm 0.0148) \mu \mathrm{g} / \mathrm{g}$ である。乙の両群における合 有水銀量は，他年代群に比べて高值である（表 8）。

各年代每に，男交間の菌牙含有平均水銀量を比較した 場合，10才台で，男性の0.1464（土0.0195） $\mu \mathrm{g} / \mathrm{g}$ は, 女性の $0.0602( \pm 0.0087) \mu \mathrm{g} / \mathrm{g}$ に比心， 有意に高值で あった。他の年代群では, 男女間に差はほとんどみられ なかった（表 8).

d. 鹋藏の含有水銀量

離蝕の程度を $\mathrm{C}_{1} \sim \mathrm{C}_{4}$ に分類し, その各群について, 霍牙含有水銀量を 調查した。平均含有水銀量は, $\mathrm{C}_{2}$ 群 （6検体）で0.0810( $( \pm 0.0237) \mu \mathrm{g} / \mathrm{g}, \mathrm{C}_{3}$ 群 (34検体)

Table 7

Mercury concentration among three regions

\begin{tabular}{|c|c|c|c|}
\hline Regions & Male & Female & Total \\
\hline A & $\begin{array}{c}20^{*} \\
0.0732 \pm 0.0132^{* *}\end{array}$ & $\begin{array}{c}14 \\
0.0580 \pm 0.0247\end{array}$ & $\begin{array}{c}34 \\
0.0670 \pm 0.0133\end{array}$ \\
\hline B & $\begin{array}{c}13 \\
0.0644 \pm 0.0168\end{array}$ & $\begin{array}{c}48 \\
0.0507 \pm 0.0014\end{array}$ & $\begin{array}{c}61 \\
0.0536 \pm 0.0051\end{array}$ \\
\hline $\mathrm{C}$ & $\begin{array}{c}38 \\
0.0725 \pm 0.0099\end{array}$ & $\begin{array}{c}30 \\
0.0896 \pm 0.0119\end{array}$ & $\begin{array}{c}68 \\
0.0800 \pm 0.0078\end{array}$ \\
\hline Total & $\begin{array}{c}71 \\
0.0712 \pm 0.0074\end{array}$ & $\begin{array}{c}92 \\
0.0645 \pm 0.0019\end{array}$ & $\begin{array}{c}163 \\
0.0674 \pm 0.0048\end{array}$ \\
\hline
\end{tabular}


で0.0685（士0.0103） $\mu \mathrm{g} / \mathrm{g}, \mathrm{C}_{4}$ 群（66検体）で 0.0745 ( \pm 0.0076$) \mu \mathrm{g} / \mathrm{g}$ であった．いずれも健常歯牙の平均 含有水銀量 $0.0545 （ \pm 0.0057 ） \mu \mathrm{g} / \mathrm{g}$ に比べて 高值であ った（表 9 ).

また, $\mathrm{C}_{3}$ 群およびC 4 群の測定偡の分散は，ともに， 健常㮀牙の場合と異なった分散を示していたが，平均值 の差の検定では，健労蕃牙と $\mathrm{C}_{4}$ 群との差のみに，有意 が涩められた。なお， $\mathrm{C}_{1}$ の歯牙は蒐集し得なかった。 e. 菌種別含有水銀量

乳娄・ 31 検体のうち, 前菻 - 8 検体の平均含有水銀量 は, $0.0714( \pm 0.0109) \mu \mathrm{g} / \mathrm{g}$ で, 日雨・23検体のそれ は $0.1093( \pm 0.0143) \mu \mathrm{g} / \mathrm{g}$ である. 永久歯では, 前蒾

(36検体) が $0.0600( \pm 0.0094) \mu \mathrm{g} / \mathrm{g}$ ，小四蒌（26検 体) が $0.0690( \pm 0.0091) \mu \mathrm{g} / \mathrm{g}$, 大曰柬 (28検体) が $0.0552 （ \pm 0.0107 ） \mu \mathrm{g} / \mathrm{g}$ ，智菌 (42検体) が0.0520（士 0.0048） $\mu \mathrm{g} / \mathrm{g}$ であった. 乳蒾の方が, 永久菌に比べて,

Table 8

Male and female mercury concentration by age

\begin{tabular}{|c|c|c|c|}
\hline Age & Male & Female & Total \\
\hline \multirow{2}{*}{$<10$} & $12^{*}$ & 8 & 20 \\
\hline & $0.0818 \pm 0.0200^{* *}$ & $0.1088 \pm 0.0286$ & $0.0926 \pm 0.0123$ \\
\hline \multirow{2}{*}{10} & 5 & 11 & 16 \\
\hline & $0.1464 \pm 0.0195$ & $0.0602 \pm 0.0087$ & $0.0871 \pm 0.0148$ \\
\hline \multirow{2}{*}{20} & 13 & 19 & 32 \\
\hline & $0.0533 \pm 0.0120$ & $0.0554 \pm 0.0089$ & $0.0545 \pm 0.0074$ \\
\hline \multirow{2}{*}{30} & 4 & i1 & 15 \\
\hline & $0.0451 \pm 0.0144$ & $0.0570 \pm 0.0135$ & $0.0538 \pm 0.0120$ \\
\hline \multirow{2}{*}{40} & 19 & 16 & 35 \\
\hline & $0.0657 \pm 0.0102$ & $0.0612 \pm 0.0164$ & $0.0636 \pm 0.0300$ \\
\hline \multirow{2}{*}{50} & 11 & 15 & 26 \\
\hline & $0.0471 \pm 0.0222$ & $0.0492 \pm 0.0048$ & $0.0483 \pm 0.0102$ \\
\hline \multirow{2}{*}{$>60$} & 7 & 12 & 19 \\
\hline & $0.1003 \pm 0.0346$ & $0.0540 \pm 0.0214$ & $0.0711 \pm 0.0203$ \\
\hline
\end{tabular}

Table 9 Male and female mercury concentration by carious degree

\begin{tabular}{|c|c|c|c|}
\hline & Male & Female & Total \\
\hline \multirow{2}{*}{ Normal } & $27^{*}$ & 30 & 57 \\
\hline & $0.0590 \pm 0.0102^{* *}$ & $0.0524 \pm 0.0047$ & $0.0545 \pm 0.0057$ \\
\hline \multirow{2}{*}{$\mathrm{C}_{2}$} & 2 & 4 & 6 \\
\hline & 0.0690 & $0.0896 \pm 0.0332$ & $0.0810 \pm 0.0237$ \\
\hline $\mathrm{C}_{3}$ & 12 & 22 & 34 \\
\hline \multirow{2}{*}{$\mathrm{C}_{4}$} & $\begin{array}{c}0.0536 \pm 0.0070 \\
30\end{array}$ & $\begin{array}{c}0.0807 \pm 0.0151 \\
36\end{array}$ & $\begin{array}{c}0.0685 \pm 0.0103 \\
66\end{array}$ \\
\hline & $0.0894 \pm 0.0125$ & $0.0621 \pm 0.0088$ & $0.0745 \pm 0.0076$ \\
\hline
\end{tabular}

* number of cases

** mean \pm S.E. $\mu \mathrm{g} / \mathrm{g}$ (dry weight) 
ことに乳田霜は，有意に含有水銀量が多い（図17）。

永久苗では，前柬と智崡との測定值の分散に有意差が みられたが，平均含有水銀量の相互間の差は，有意では ない.

\section{f. 䨑牙組織別含有水銀量}

検体菌牙をエナメル質と象牙質とに分離出来た73検体 について，雨牙組織別の含有水銀量を検討した.エナメ 几質（男性11検体・女性21検体）は0.0768（士0.0107） $\mu \mathrm{g} / \mathrm{g}$ ，象牙質（男性15検体・女性26検体）は0.0473（士 0.0064） $\mu \mathrm{g} / \mathrm{g}$ であった.すなわち，エナメル質では， 象牙質より水銀含有量が多い傾向にある（図18）。

IV 小 括

健常米牙に扔ける含有水銀量は，乳霜で0.0568（士0. $0081) \mu \mathrm{g} / \mathrm{g}$, 永久䨑前崡で $0.0567( \pm 0.0031) \mu \mathrm{g} / \mathrm{g}$, 永久歯曰菡で $0.0690( \pm 0.0222) \mu \mathrm{g} / \mathrm{g}$ ，永久歯智菌で $0.0486 （ \pm 0.0062 ） \mu \mathrm{g} / \mathrm{g}$ であり，各群相互間の差に有 意はなく，健常备牙・57検体の平均含有水銀量は0.0545 (士0.0057） $\mu \mathrm{g} / \mathrm{g}$ である. 年代・性別差および地域差

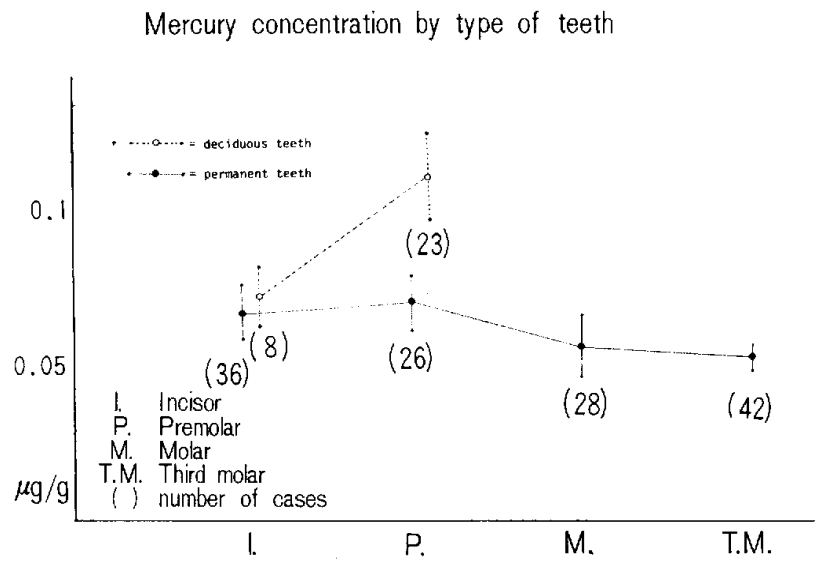

Fig. 17

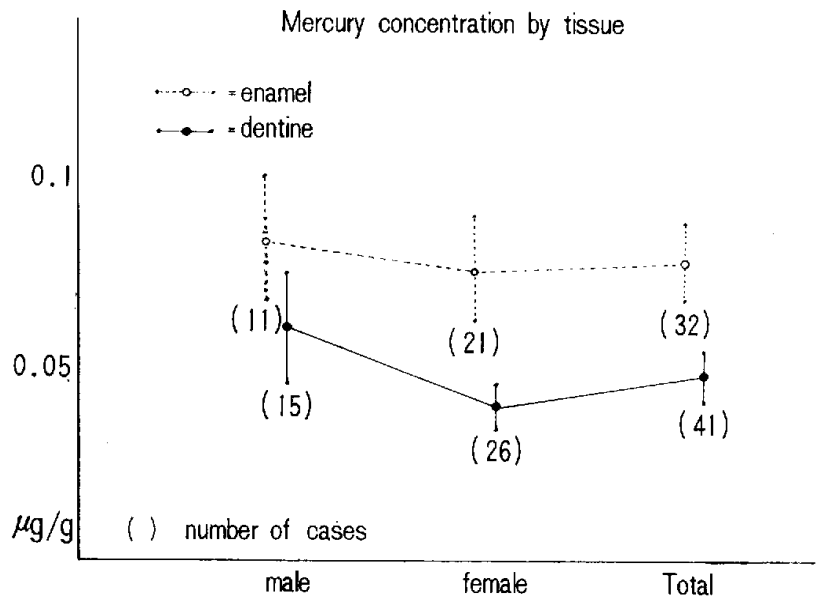

Fig. 18
も，ほとんどなく，その含有量は比較的安定している．

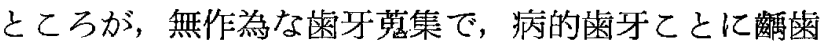
が採取されると，その平均含有水銀量は多くなり，その

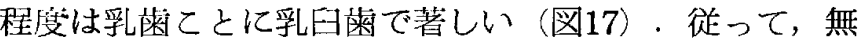
作為蒐集潾牙の検討で，乳蒾の平均含有水銀量が，永久 椈に比べて，有意に高い值を示したのは，䝆蝕乳菌の含 有水銀量が多かったことに由来するもので，前述のよう に，健常䨑牙では，乳菌も永久歯も含有水銀量に，差は ないものと考えられる。

また，無作為䈭集菡牙を 3 地域に分類し対比したとと ろ，C地区で， $0.0800 （ \pm 0.0078 ） \mu \mathrm{g} / \mathrm{g}$ ，他 2 地区 に比べ，高い值を示し，ととに女性で有意な高值 $〔 0.08$ $96 〔 \pm 0.0119) \mu \mathrm{g} / \mathrm{g}]$ を示した. このととも，そのほ とんどの検体が離䨑であったととによる.

さらに歯牙を組織別にみた場合，象牙質に比べて，工 ナメル質に，含有水銀量は多かったが，両者間の差に有 意はなかった。

なお，含有水銀量を検出出来なかった歯牙 4 検体のう ち， 2 検体は健常齿，他の 2 検体は硧菌であった。一 方, 含有水銀量が $0.4 \mu \mathrm{g} / \mathrm{g}$ 以上の 9 検体は, すべて治療 崡牙であった。

\section{D. 歯牙含有カドミウム（Cd）罟に関する検討}

\section{I 一般的事項}

北海道大夕翇地区（A）・北九州市地区（B）・宮崎 県諸塚地区（C）の3地区で, 歯科外来治療時に, 無作 為に蒐集された男性歯牙・28検体，女性菌牙・42検体， 計70検体について，含有 Cd 量を分析定量した. うち健 常菡牙は25検体（男性 8, 女性17）であった。

試料作製に際しては，含有水銀量の検討の場合と同様 な方法で湿式庅化して後，水を加えて $10 m \ell$ とた。本溶 液について, $\mathrm{Cd}$ 量を定量し, 乾燥重量 $1 \mathrm{~g}$ 当りの米牙 含有Cd量を算定した.

Table 10 Cadmium concentration by age

\begin{tabular}{r|r|l}
\hline \multicolumn{1}{c|}{ Age } & Cases & Mean \pm S.E.* \\
\hline$<10$ & 5 & $0.5076 \pm 0.1794$ \\
10 & 6 & $0.4565 \pm 0.1068$ \\
20 & 17 & $0.5554 \pm 0.0741$ \\
30 & 8 & $0.5597 \pm 0.1470$ \\
40 & 18 & $0.4617 \pm 0.0693$ \\
50 & 8 & $0.5027 \pm 0.1049$ \\
$>60$ & 8 & $0.4099 \pm 0.0755$ \\
\hline
\end{tabular}

* $\mu \mathrm{g} / \mathrm{g}(\mathrm{dry}$ weight $)$ 
Table 11

Cadmium concentration among three regions

\begin{tabular}{c|c|c|c}
\hline Regions & Male & Female & Total \\
\hline A & $8^{*}$ & 15 & 23 \\
& $0.4393 \pm 0.0557^{* * *}$ & $0.4088 \pm 0.0959$ & $0.4287 \pm 0.0547$ \\
B & 23 & 2 & 25 \\
& $0.5667 \pm 0.1497$ & $0.5045 \pm 0.0632$ & $0.5095 \pm 0.0616$ \\
C & 11 & 11 & 22 \\
\multirow{2}{*}{ Total } & $0.5464 \pm 0.0787$ & $0.6095 \pm 0.0825$ & $0.5786 \pm 0.0600$ \\
& $0.4905 \pm 0.0480$ & $0.5138 \pm 0.0480$ & $0.5045 \pm 0.0346$ \\
\hline & $*$ number of cases & & \\
& $* * \mu \mathrm{g} / \mathrm{g}$ (dry weight $)$ &
\end{tabular}

\section{II 健常歯牙の含有 $\mathrm{Cd}$ 量}

健常柬牙・25検体の平均含有 Cd 量は, $0.5201( \pm 0.0$ 520） $\mu \mathrm{g} / \mathrm{g}$ であった.

\section{III 無作為蒐集雨牙の含有Cd量}

\section{a . 含有Cd量}

上記の健常雨牙・25検体を含む，無作為蒐集曾牙・70 検体の平均含有 $\mathrm{Cd}$ 量は, $0.5045( \pm 0.0346) \mu \mathrm{g} / \mathrm{g}$ で, 健常雨牙のみを対象とした場合の0.5201（士0.0520） $\mu \mathrm{g}$ /gに比べわずかに低值であるが，その差には有意はな W.

b. 含有 $\mathrm{Cd}$ 量の年令別・性別・地域別差

無作為葸集歯牙・70検体を，年令別（表10）打よび性 別・地域別（表11）に分類し，その平均含有 $\mathrm{Cd}$ 量を対 比検討した．各群間の差に有意はない．

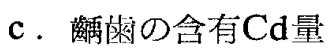

鹋菌・45検体を，㽬蝕の程度別に分類し，その平均含 有 $\mathrm{Cd}$ 量を検討したとてろ， $\mathrm{C}_{2}$ 群（6検体）は0.2800( $\pm 0.1025) \mu \mathrm{g} / \mathrm{g}, \mathrm{C}_{3}$ 群 (20検体) は0.4753( \pm 0.0632$)$ $\mu \mathrm{g} / \mathrm{g}, \mathrm{C}_{4}$ 群 (19検体) は0.5590(土0.0671) $\mu \mathrm{g} / \mathrm{g}$ であ った.

Table 12

Cadmium concentration by carious degree

\begin{tabular}{c|c|c}
\hline Degree & Cases & Mean \pm S.E. $\mu \mathrm{g} / \mathrm{g}^{*}$ \\
\hline Normal & 25 & $0.5201 \pm 0.0520$ \\
$\mathrm{C}_{2}$ & 6 & $0.2800 \pm 0.1025$ \\
$\mathrm{C}_{3}$ & 20 & $0.4753 \pm 0.0632$ \\
$\mathrm{C}_{4}$ & 19 & $0.5590 \pm 0.0671$ \\
\hline
\end{tabular}

*dry weight
$\mathrm{C}_{2}$ 群で最も低値を示し，ことに $\mathrm{C}_{4}$ 群に比べて 有意に 少ない，また， $\mathrm{C}_{2}$ 群の平均含有 $\mathrm{Cd}$ 量は, 健常歯牙の平 均含有Cd量 $0.5201( \pm 0.0520) \mu \mathrm{g} / \mathrm{g}$ に比べても, 低值 である.しかし，その差は有意ではない（表12）。

d. 歯種別含有 $\mathrm{Cd}$ 量

乳歯・ 8 検体の平均含有Cd量は0.5317 $( \pm 0.124) \mu \mathrm{g}$ $/ \mathrm{g}$ で，永久蒾・62検体の平均含有 Cd量は0.5038（ \pm 0.0 436） $\mu \mathrm{g} / \mathrm{g}$ であり，その両者間の差に有意はない.

永久南をさらに歯種別に分類したところ，その平均含 有Cd量は，前霜 (13検体) で0.3116（士0.0663） $\mu \mathrm{g} / \mathrm{g}$,

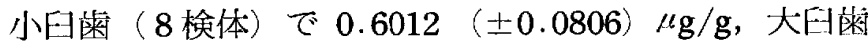
(14検体) で0.5364 $( \pm 0.0870 ） \mu \mathrm{g} / \mathrm{g}$, 智歯 (27検体) で0.5506 $( \pm 0.0700) \mu \mathrm{g} / \mathrm{g}$ となる. 前柬の平均含有 $\mathrm{Cd}$ 量は，小四菡・智崡のそれに比べて有意に低い値を示し た (図19).

e . 歯牙組織別含有Cd量

エナメル質と象牙質に分離出来た検体について，それ ぞ机の含有 $\mathrm{Cd}$ 量を定量し，平均值で対比検討した之こ ろ，エナメル質（8検体）の0.5365（ $\pm 0.0959 ） \mu \mathrm{g} / \mathrm{g}$

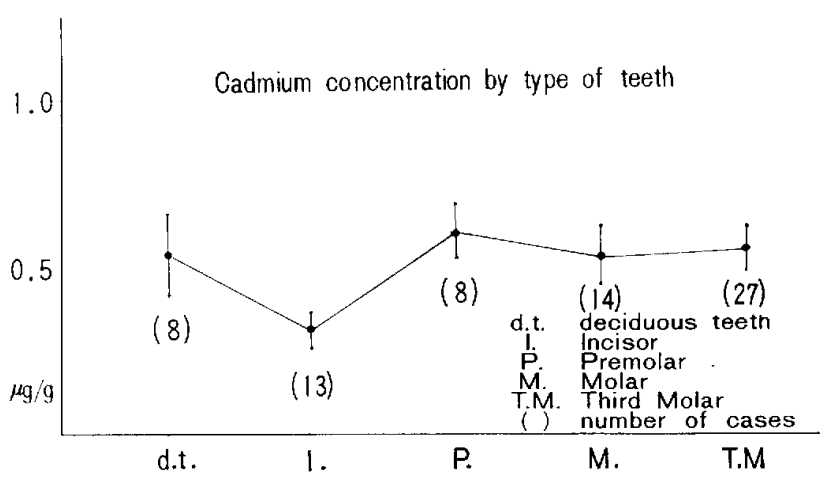

Fig. 19 
は，象牙質（14検体）の0.3628（土0.0707） $\mu \mathrm{g} / \mathrm{g}$ に比 べ高值である。しかし，その差は有意ではない(表13)。

Table 13

Cadmium concentration by tissue

\begin{tabular}{l|c|c}
\hline & Cases & Mean \pm S.E.* \\
\hline Enamel & 8 & $0.5365 \pm 0.0959$ \\
Dentine & 14 & $0.3628 \pm 0.0707$ \\
\hline
\end{tabular}

$* \mu \mathrm{g} / \mathrm{g}$ (dry weight)

IV 小 括

健常歯牙・25検体の平均含有Cd 量は0.5201 $( \pm 0.052$ 0) $\mu \mathrm{g} / \mathrm{g}$ であり, 無作為蒐集荬牙・70検体の平均含有 $\mathrm{Cd}$ 量は0.5045 ( \pm 0.0346$) \mu \mathrm{g} / \mathrm{g}$ であった. 年令別, 性別, 地域別差はみられなかった．また，乳霜と永久菊との差 にも，有意はなかった。

畆雨の含有 $\mathrm{Cd}$ 量を，その程度別にみた場合， $\mathrm{C}_{2}$ 群 6 検体）の平均含有 $\mathrm{Cd}$ 量は0.2800（士0.1025） $\mu \mathrm{g} / \mathrm{g}$ で, $\mathrm{C}_{4}$ 群（19検体）の0.5590（土0.0671） $\mu \mathrm{g} / \mathrm{g}$ に比心，有 意に少なく，䶊蝕の程度が進行するに伴い，含有 $\mathrm{Cd}$ 量 は増加する傾向がうかがわれた。しかし， $\mathrm{C}_{2}$ 群は検体数 も少なく，標準詋差も大きい，従って，なお向後の検討 を要する．永久雨・62検体を䨑種別にみた場合，前雨 (13検体) の0.3116（ $\pm 0.0663 ） \mu \mathrm{g} / \mathrm{g}$ は，小臼菊 $(8$ 検体）の $0.6012 （ \pm 0.0806 ） \mu \mathrm{g} / \mathrm{g}$ ，智事 (27検体) の 0.5506（ $\pm 0.0700 ） \mu \mathrm{g} / \mathrm{g}$ に比べ，有意に低值である.

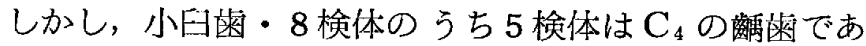
り, また, 前雷13検体のう $5 \mathrm{C}_{2} \cdot \mathrm{C}_{3} \cdot \mathrm{C}_{4}$ の各 3 検体を 除いた，健常菌牙・4 検体の平均含有Cd量流0.5090(土 $0.0917) \mu \mathrm{g} / \mathrm{g}$ であり, 智歯・27検体のうち， $\mathrm{C}_{2} \cdot 1$ 検 体, $\mathrm{C}_{3} \cdot 11$ 検体, $\mathrm{C}_{4} \cdot 1$ 検体を除外した健常䨑牙・14検 体の平均含有Cd量は0.5137（士0.0800） $\mu \mathrm{g} / \mathrm{g}$ で, 健常 荬牙のみでは，その相互間の差に有意はみられない。

\section{E. 考察ならびに総括}

原子吸光分析法の普及に伴い，歯牙含有の微量金属に 関する知見の報告も数多い.しかし，歯牙含有の水銀量 を定量分析した報告には，いまだ接し得ていないのみな らず， Cd量についても，2〜3の報告7.10-12)をみる にすぎない。

最近，環境污染金属として，水銀・ Cdが共に，注目 されているのは，すでに周知のとてろである.

著者は，原子吸光法を用い，雬牙含有の水銀および Cd量の定量分析を試み，興味ある若干の知見を得た。 ここに，その大要を総括し，考察を加えて報告する，
先ず，㐘牙含有の水銀量の測定に当っては，還元気化 方式を採用し，原子吸光分析法で定量した。その方法の 詳細は，長谷川ら $(1972)^{1.21}$ ，菅野 ${ }^{(1973)^{3}}{ }^{1}$ などの記 載に準じており，総水銀量を測定対象としたものであ る。

一方, Cd量の定量には，試料にジエチルジチオカル バミン酸ナトリウム (DDTC) を加えてキレート化合物 とし，てれをメチルイソブチルケトン（MIBK）で抽出 して，その抽出液について原子吸光法を行なう方法が， 一般的である(鈴木ら：1973）"

しかし，本法により，歯牙含有 $\mathrm{Cd}$ 量を測定し，報告 された值も，変動の幅が大きいようである，従って，今 回は, 試料をアセチレン・空気混合ガスで然焼還元し, 原子吸光分析に際しては， $\mathrm{D}_{2}$ ランプを用いて，光学的 亿散乱線を除去し，他元素による内部干涉を除外補正す る方法5゙よった。

基礎実験を重ね，歯牙含有の水銀 および Cd量を分析 定量するに際し，著者の方法が，ほぼ満足すべき定量法 であるととを確認し，北海道大夕張地区（A）・北九州 市地区（B）・宮崎県諸塚地区（C）で，無作為に蒐集 された歯牙検体について，その含有水銀量抢よび Cd量 を測定した。ことに，從来，その報告をみない菌牙合有 水銀量については, 検出基礎単位を $0.01 \mu \mathrm{g}$ とすること により定量可能となった。

無作為に蒐集された霜牙176検体について，含有水銀 量の頻度分布ヒストグラム（図20）をみると，ピークは 低值側に偏位しており，污染物質特有の分布〔Schütte $(1964)^{6)}$, 大塩 $(1973)^{7)}$ 】が示唆された.

健常菌牙・57検体の平均含有水銀量は0.0545（ \pm 0.00 57） $\mu \mathrm{g} / \mathrm{g}$ であり，乳爾と永久崡の平均含有水銀量の差 には，有意はみられなかった。

Disiribution of mercury concentration

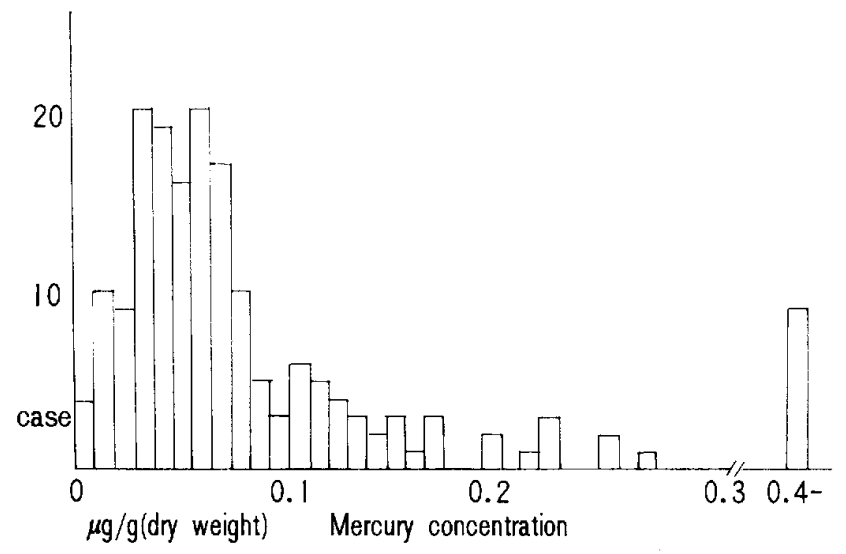

Fig. 20 


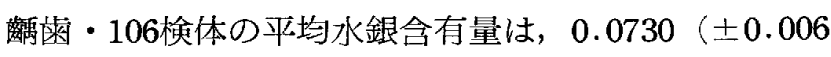

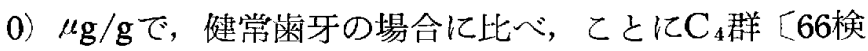

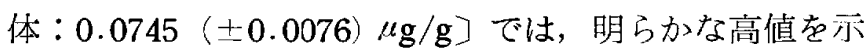
した.

健常蒾牙を含む無作為蒐集筜牙の平均含有水銀量の対 比検討で，乳米群，10才未満の㐘牙群で，平均含有水銀 量が，それぞれ，0.0995（土0.0106） $\mu \mathrm{g} / \mathrm{g}, 0.0926$ (土 $0.0123 \mu \mathrm{g} / \mathrm{g}$ と有意に高かったのも，検体雨牙として，

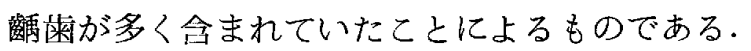

$0.4 \mu \mathrm{g} / \mathrm{g}$ 以上の含有水銀量が検出された 9 白牙は，い ずれも治療雨でアマルガムなど函科用充填物の除去を行 なったにもかかわらず，著しく高值を示していた。この ことは，歯科治療上の問題点として，今後，なお長期に 亘る経過観察が肝要なように思われる。

先に述べたように，爾牙含有水銀量のヒストグラムか ら，水銀は，齒牙に打ける必須微量金属ではなく，活染 金属と考えられる．青木 $(1974)^{81}$ は，メチル水銀が雬 牙に沈着し得ることを奏験的に証明している。また，メ チル承銀やエチル水銀など有機水銀が，自然界で無機化 される一方, 無機水銀は, 自然界でメチル化されること

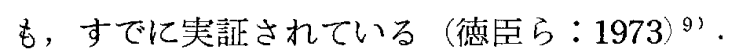

古くより，無機水銀中毒症は，職業病として知られて きており，最近では，公踳污染としての有機水銀中毒址 もまた，姏の耳目を集めている。このような時期に際し 国内 3 地区より無作為に䃬した㐘牙検体について，含 有水銀量を検出定量し得たことは，甚だ意義深いものに 思われる。

ちなみに，無作為蒐集谏牙・176検体中，含有水銀量 を検出し得なかった甬牙は 4 検体で，うち2検体は北九 州市地区，他の 2 検体は諸塚地区で蒐集されたものであ る.また，健常菌牙で，含有水銀量が $0.208 \mu \mathrm{g} / \mathrm{g}$ にも よんでいた 1 検体は，北海道大夕張地区のものであっ te.

粜牙の含有 $\mathrm{Cd}$ 量も, 水銀の場合と同しくく, 国内 3 地 域で, 無作為に䈭集された曾牙・70検体について, 分析 定量されている，その平均含有 Cd量は0.5045（士0.034 6) $\mu \mathrm{g} / \mathrm{g}$ あり, 健常橉牙・25検体に扔ける平均含有 Cd 量は0.5201（土0.0520） $\mu \mathrm{g} / \mathrm{g}$ であった.

一般に，Cdの原子吸光分析法による定量には，有機 溶媒に抽出する方法が，用いられている，ての方法を用 い，歯牙の含有 $\mathrm{Cd}$ 量を测定した報告で，金子（1972） ${ }^{10}$ は平均 $0.20 \mu \mathrm{g} / \mathrm{g}$ （対数平均值常数変換 $0.12 \mu \mathrm{g} / \mathrm{g}$ ) で あったと述べ，大塩 $(1973)^{71}$ は，0.6〜 $1.4 \mu \mathrm{g} / \mathrm{g}$ の間に 分布頻度が高かったととを示説している．大塭の報告
は，乳菌を対象とした值ではあるが，試料量と検出量の 基礎的な検討に摖し，永久瘅と乳菌が同一線上に，直線 的にプロットされることを図示しており（山本・大塩： $1973)^{11}$ 永久㐘の含有 $\mathrm{Cd}$ 量も，乳蒾とほぼ同様な值を 示すものと考えられる.

著者の方法で, 定量した棶牙の平均含有 Cd量は, 0.5 $\mu \mathrm{g} / \mathrm{g}$ 前後であり, 金子, 大塩の報告量のほほ中間の值 である。

次に，著者が作製した，無作為䈭集歯牙・70検体の含 有 $\mathrm{Cd}$ 量頻度分布ヒストグラム（図21）では，歯牙にお ける Cdの非必須性を論議することは出来ない，大塩の 亦したヒストグラムでも，わずかに non-essential の 傾向を示したにとどまる.

しかし，古くより，歯牙における Cd 黄色侵か知られ ており,イタイイタイ病発生地域で歯牙 $\mathrm{Cd}$ 量が有意に 増加していた報告（岩倉：1972）12るみられ， Cd も非 必須の污染金属として理解されている現状のようであ る.

確かに, 蔝牙硬組織は, 一旦, 形成されると, 他の人 体組織に比べて, 著しく安定性であり, 発生期の体液イ オン組成をある程度反映して記録する特性を有している

(Brudevold, et al. : 1963 ${ }^{6}{ }^{6}$. また最近, 青木 (1974)

8) は, 崡牙発生過程の組織縕胞では, かなり容易にメチ 儿水銀が取込まれることを丰験的に報告している。

従って, 現段階における米牙含有水銀量を知ること は，今後の水銀污染に関する疫学的な調查を行なうに当 り，極めて貴重な資料となる。乙こに，著者の方法によ

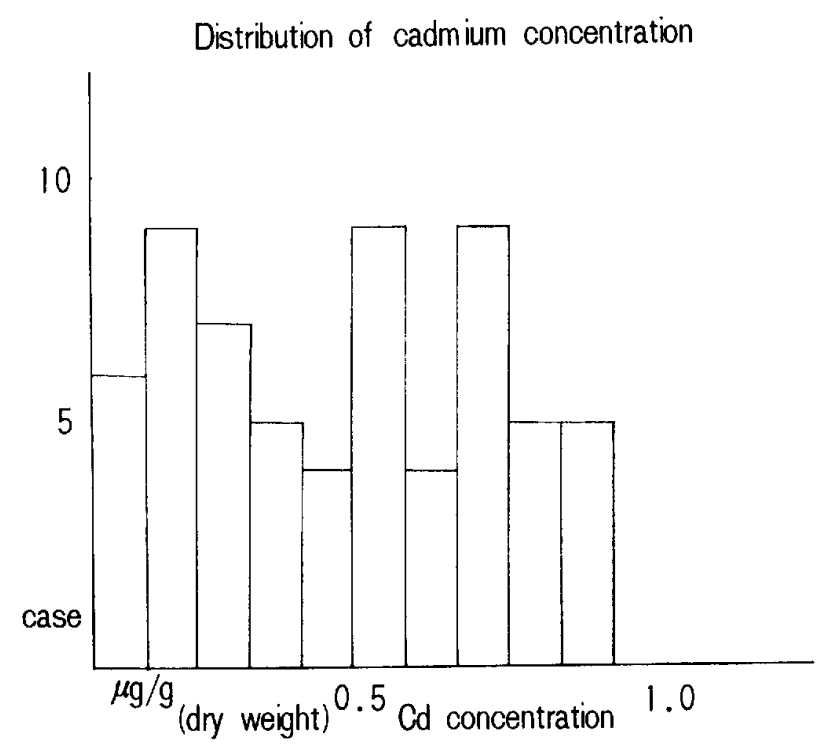

Fig. 2.1 
り定量可能となった菌牙含有水銀量を，ことに意義深い ものとして報告する次第である.

なお，歯牙含有の Cd 量についても，検討結果を記述 したが，頻度分布ヒストグラムからは，污染金属とは断 定出来ない一面もあり，また，当然，污染が予想された 群馬県安中地区の住民橉牙でも含有 $\mathrm{Cd}$ 量は高値を示さ なかったという報告（金子・1972）10)もみられる.

さらに, 田辺 $(1968)^{14}$ は, Cd50ppm 飲料水で飼育中 のラット画牙では，2.03ppmを検出し得たが，投与中止 1 カ月後には，0.23ppmにすぎなかったととを報告して いる.

従って，日腔内自浄作用なども考慮して，岩倉 (1972) 12)のいうょうに，エナメル質と象牙質とに分離し，そ の含有量を対比検討するなど, 歯牙の含有 Cd 量につい ても，今後の検討をまた权ばならない問題も数多いよう である。

ちなみに，今回の検討結果では，柬牙組織別にみた場 合, 含有水銀量および Cd 量とも，エナメル質に多い傾 向がみられた.

また，無作為に蒐集された苜牙在刘象とした，今回の 定量結果では, 平均含有水銀量, $\mathrm{Cd}$ 量とも, 㽬藏につ いて十分の配慮を行ない解析すると, 性差・年令差・地 域差などはみられず, また, 乳菌と永久雪, 前菌と曰荿 など䨑種による差も有意は綛められなかった。

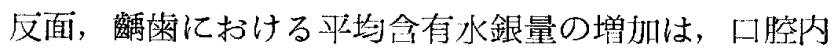
における水銀污染（沈着）を示唆したものかと考えられ る. 今後とも長期にわたって, 撂椈の含有水銀量の推移 は検討さるべきである。

\section{F. 結 語}

原子吸光分析法を用い，電牙の含有水銀量およびカド ミウム量を測定した，水銀量の定量には還元気化方式を 採用し，カドミウム量の定量には $\mathrm{D}_{2}$ ランプを用い内部 干涉老除外補正した。

北海道大夕張地区・北九州市地区・宮崎県諸塚地区 で，無作為に蒐集された歯牙を検体として，分析定量さ れた含有水銀量およびカドミウム量は次の通りである.

1. 健常娄牙・57検体の平均含有水銀量は 0.055 (土 0.006) $\mu \mathrm{g} / \mathrm{g}$ であった.

2. 健常乳苳・ 8 検体および健常永久歯・49検体の平 均含有水銀量は，それぞれ， $0.057( \pm 0.008) \mu \mathrm{g} / \mathrm{g}$, $0.055( \pm 0.010) \mu \mathrm{g} / \mathrm{g}$ で，両者間の差に有意はみられ なかった。

3. 踊歯の平均含有水銀量老, 龉蝕の程度別に検討し たところ， $C_{2}$ 群 (6検体) は0.081 ( \pm 0.024$) \mu \mathrm{g} / \mathrm{g}, \mathrm{C}_{3}$
群 (34検体) は $0.069( \pm 0.010) \mu \mathrm{g} / \mathrm{g}, \mathrm{C}_{4}$ 群 (66検体) は0.075( \pm 0.008$) \mu \mathrm{g} / \mathrm{g}$ で, 乙とに $\mathrm{C}_{4}$ 群の值は, 健常 歯牙の平均含有水銀量に比べて，有意の高值を示した。

4. 含有水銀量が $0.4 \mu \mathrm{g} / \mathrm{g}$ 以上 99 検体は, いずれ も，アマルガム充填などの治療㐘牙であった。

5. 從って, 無作為蒐集茵牙を対象検体とし, その含

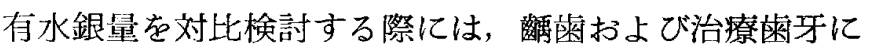
ついて格別の配慮が肝要である.

健常雨牙のみを対象検体とした場合には, 性別・年令 別・霜種別および地域別の差には有意はみられなかっ た.

6. 健常爾牙・25検体の平均含有カドミウム量は, 0 . $52( \pm 0.05) \mu \mathrm{g} / \mathrm{g}$ であった。

7. 歯牙組織別にみた場合, エナメル質で, 平均含有 水銀量およびカドミウム量は，ともに，象牙質よりも多 い傾向がみられた。

以上の定量結果を報告し, 環境污染の立場から, 若干 の考察を加えた.ことに函牙含有水銀量に関しては, 従 来, 報告がなく, 意義深い知見である。

(稿を終るにあたり，終始御烈篤な御指導と御校閲を 賜った恩師，九州薁科大学第 2 口腔外科学教室池尻茂教 授, 九州菌科大学外科学教室草場威稜夫教授に心から感 謝の意を表します．また本研究に御協力を頂いた教室員 一同に感謝致します。

\section{引用 文 献}

1）長谷川敬彦・新関满・伊知地令子・他：炎なし原 子吸光分析に上る水銀計の試作之有機水銀, 無機水銀の 定量, 環研年報 XXIII：167-173，1972.

2 ) 長谷川敬产・伊知地令子 - 新関満：環境気中水銀 の補集と測定，環研年報 XXIV：201-204，1972.

3) 管野三郎：重金属 (原子吸光光度法) , 日本臨床 $31: 1955-1965,1973$.

4）鈴木正己・武内次夫 - 田村正平 - 他：原子吸光分 析の実際, 南江堂, 1973.

5) 日立製作所版：原子吸光光度計測定解説， 1973.

6 ) Schütte, K. H. : The biology of the trace elements, Their role in nutrition, Crosby Lockwood \& Son Ltd, London, 1964 . (大塩英雄 ${ }^{7)}$ 上り 引用)

7) 大塩英雄：乳函中のカドミウム, 业鉛および鉛の 含有量について，東京および富山地区における歯種別含 有量の比較, 口腔衛生会誌 $23: 208-222,1973$.

8) Aoki. T. : Distribution of Hg-Methylmercuric Chloride in tissue cells in the field of oral 
cavity during the process of dental development and its charge in time course. J. Kyushu Dent. Soc. $28: 401-430,1974$.

9 ) 徳臣晴比古 - 山村定光 : 水銀, 日本臨床 $31: 14$ 89-1494, 1973.

10）金子芳洋：崡の微量金属に関する研究，口腔衛生 会誌 $22: 79-97,1972$.

11）山本十糸子, 大塩英雄：原子吸光分析法汇上る菌 質中のカドミウム，覀鈶および鉛の定量法について， 口
腔衛生会誌 $23 ： 192-207,1973$.

12）岩倉政城：Cadmium 污染地区における歯質中 Cadmiumについて,口腔衛生会誌 $22: 1-9,1972$.

13) Brudevold, F., et al. : A study of zinc in human teeth, Arch. Oral Biol. 8 : 135-144, 1963.

14）田辺釧：慢性カドミウム中毒の実験的研究一特に ラッテに扔ける Cd 体内蓄積について一, 金大十全医学 誌 $76: 181-197 ， 1968$. 